\title{
1. Enhancing social partners' and social dialogue's roles and capacity in the new world of work: Overview
}

\author{
Youcef Ghellab and Daniel Vaughan-Whitehead
}

\section{INTRODUCTION}

The profound change sweeping through the world of work involves four major drivers: technological innovation, demographic shifts, climate change and globalization. It poses serious challenges, but also opens new opportunities for social dialogue and the role of the social partners, together with public authorities, in the governance of the world of work. While social dialogue institutions and mechanisms, including collective bargaining, have long been a feature of European Union (EU) countries, sometimes for decades, questions have been raised about the ability of social dialogue to rise to the new challenges and opportunities, and deliver sustainable socio-economic outcomes. These questions have been raised at a time when trade unions and employers' organizations are seeking to adapt to the massive transformations in the global organization of labour and production, and labour administrations, on their part, are struggling to cope with the challenge of enhancing labour market performance and workplace compliance.

The International Labour Organization's (ILO's) 'Centenary Declaration for the Future of Work' (ILO 2019) emphasized that social dialogue, including collective bargaining and tripartite cooperation, contributes to successful policy and decisionmaking in its member states. The Resolution adopted by the International Labour Conference (ILC) in June 2018 underlined that social dialogue and tripartism are essential for democracy and good governance (ILO 2018). Also, it stipulated that 'social dialogue plays an important role in shaping the future of work, taking into account particular trends of globalization, technology, demography and climate change' (ILO 2018).

Key policy statements and documents emanating from various EU institutions also stress the critical importance of social dialogue and the involvement of social partners in policy-making as an important governance tool (Eurofound 2019). For instance, the European Commission (EC) stated that:

an effective and well-functioning social dialogue should be fostered to promote welfare in the EU. This can only be achieved by promoting social partners' capacity, by respecting their autonomy and strengthening their role in the design and implementation of reforms and policies and by actively involving the social partners at all stages of policymaking and implementation in line with the European Pillar of Social Rights. (EC 2017, p. 59) 
The EC also emphasizes that 'Social dialogue is rooted in the history of the European continent, and this distinguishes the Union from most other regions of the world. Accordingly, in its various forms in the different Member States, social dialogue is a component of democratic government and also of economic and social modernization' (see EC 2002, p. 6).

The Covid-19 pandemic, which has hit hard most countries around the world, including the EU, has further highlighted the critical role of social dialogue in helping governments and social partners to address complex situations (ILO 2020). In many European countries, bipartite and tripartite initiatives have been launched to contain the virus and to mitigate its social and economic effects on workers and enterprises, and to promote a safe return to work.

Against this backdrop the ILO and the EC decided to launch a new project aimed at analysing and documenting how the social partners in EU countries are endeavouring to adapt to these changes and what challenges they have been facing in this regard. The project seeks also to identify the many good practices of social dialogue that are emerging in various countries, as well as the action of public authorities aimed at enhancing the role of social dialogue, including collective bargaining, in tackling the new challenges and opportunities in the new world of work, while at the same time supporting the autonomy of the social partners.

This project builds on earlier collaboration between the ILO and the EC in the field of industrial relations and social dialogue, ${ }^{1}$ and takes a longer-term perspective with a view to strengthening the social partners' knowledge of long-term trends in the changing world of work, notably by facilitating mutual learning between them.

\section{METHODOLOGY}

The most original feature of this project is its participatory nature: the social partners at all levels (international, EU and national) have been involved at all stages in the design and implementation of its various activities. Figure 1.1 highlights the process that was followed for this project. To begin with it the social partners were extensively involved in the design and implementation of the project. In addition, there were nearly two years of work by a group of high-level researchers, complemented - finally - by a survey carried out by the ILO among national social partners to obtain their feedback on the current and potential role of national social dialogue institutions to address current and future challenges in the world of work. All the results were discussed in a final workshop that gave the social partners the opportunity to give feedback on experts' reports, share good practices and exchange policy experiences. ${ }^{2}$ The quotes in the Foreword to this volume present some of the inputs of by the various policy actors. This volume was then finalized to include the main highlights of these discussions.

\subsection{Geographical Coverage}

The social partners were asked, first, to help to define the geographical scope of the project. They decided that it should cover not only EU member states (its original purview), but also extend to all the EU candidate countries and potential countries. 


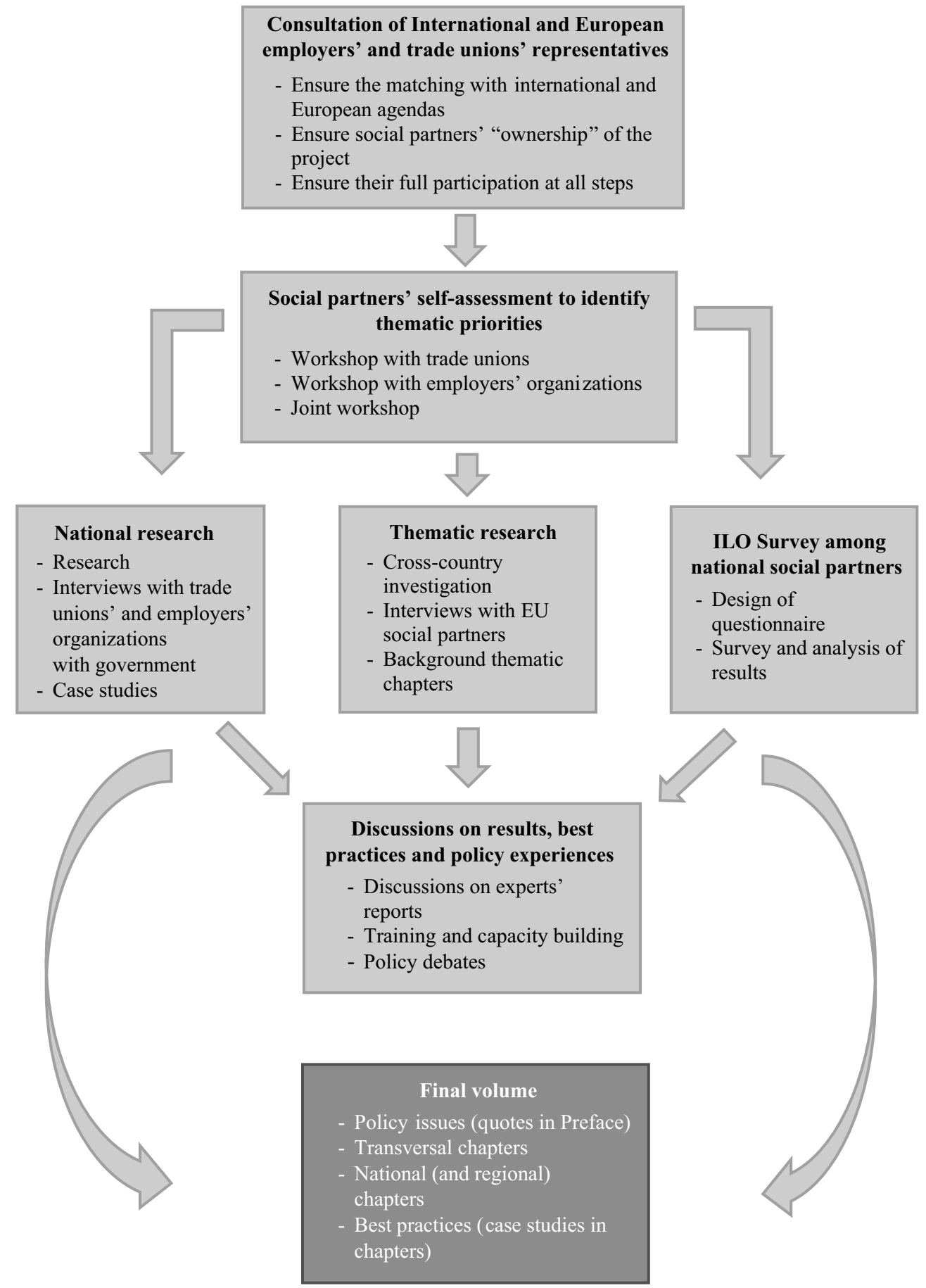

Figure 1.1 Project process and participation 
The social partners in the latter have not yet had the opportunity to participate in the EU social dialogue, which represents a forum in which the social partners from current member states discuss the challenges they face in the world of work, notably through the discussion of items such as digitalization. At the request of both employers' and workers' groups, coverage was thus extended to 34 countries. In addition to the EU27 countries and the United Kingdom, we covered candidate countries such as Albania, Bosnia and Herzegovina, Montenegro, the Republic of North Macedonia, Serbia and Turkey.

This introductory chapter covers these 34 countries, synthesising the main project's results, while also presenting the results of the survey on social dialogue institutions carried out by the ILO among the social partners from these 34 countries. Also, a limited number of countries were selected for more in-depth national research, with country case studies and reports. These countries were selected on the basis of various criteria, such as location and their experience within the EU, with a geographical balance between established EU countries from the north (Ireland and Sweden), Centre (France and Germany) and the south (Italy, Spain and Greece) of Europe; relatively recent new EU member states from central and eastern Europe (the Baltics states, the Czech Republic, Poland and Romania); then countries from the Adriatic area (covered in the relevant chapter, with both EU member states, such as Croatia and Slovenia, and candidate countries, such as Albania, Bosnia and Herzegovina, Montenegro, the Republic of North Macedonia and Serbia); and, finally, Turkey as another South-East candidate country. Beyond the national reports, two chapters cover various countries from a specific geographical area: Chapter 16 on the Adriatic countries and Chapter 17 on the three Baltic states.

In addition to the national chapters, this volume also presents three cross-country transversal chapters that cover three main aspects of the new world of work that are important for social partners and social dialogue (see next section).

\subsection{Main Topics under Focus}

At the beginning of the project, the social partners proposed choosing the topics concerning the world of work that they believe pose the most challenges and would benefit most from the research component of the project. As a consequence, national workers' and employers' organizations themselves selected three joint topics at the outset. Significant research was then carried out in the thematic areas thus defined, and the comparative results - with real examples - are presented in the next three transversal chapters ( 2 to 4 ). These thematic background chapters are complemented with research and reports at national level (in 11 national chapters, 5 to 15) and also at regional level (with Chapter 16 on the Adriatic region and Chapter 17 on the Baltic states), with a similar structure around the same three topics, while also addressing other more country-specific trends and challenges. Beyond carrying out research, both national and thematic experts were asked to systematically collect social partners' views on the challenges, opportunities and perceived priorities moving forward. This was carried out in the form of interviews with leaders and experts from trade unions' and employers' organizations at national and sectoral level. National experts also interviewed government representatives, generally those in charge of social dialogue, to obtain their views on the challenges encountered in the world of work by social partners and social dialogue institutions. The views of all these actors are reported in the following chapters, sometimes in the form of direct quotes and statements. 


\section{THE MAIN CHALLENGES AND OPPORTUNITIES IDENTIFIED BY THE SOCIAL PARTNERS}

A launch event was organized at the ILO in Geneva on 7-8 February 2019 to allow national employers' and workers' representatives from all the relevant European countries to discuss the challenges and opportunities at play in the changing world of work and select the topics on which they believe they should obtain more information, including concrete examples of good practice, to expand their knowledge base and strengthen their capacity to address them in the future. This event was organized in two rounds with, on the first day, two separate meetings of employers' and workers' organizations with the aim of preparing a list of topics. The two groups then joined together, on the second day, to present their topics and agree on what would be addressed in common during the course of the project, notably through the research work to be carried out by high-level experts.

The three topics selected by the social partners were as follows.

\subsection{Topic 1: Strengthening the Social Partners' Representativeness and Increasing their Institutional Capacity to Shape Labour Markets through Social Dialogue and Consultative Processes}

This topic was influenced by social partners' acknowledgement that strong and representative employers' and workers' organizations are key for the legitimacy and effectiveness of social dialogue. Social partners in many countries face challenges related to stagnating or declining membership and the need to be proactive to retain and recruit new members.

The chapters of this volume provide examples of various initiatives of the social partners to increase membership by reaching new members, including among categories that are traditionally difficult to organize. On the employers' side, attempts have been made, for example, to reach potential new members among small and medium-sized enterprises, where management are generally less keen to join an employers' organization. This example is developed in the chapter on Poland. On the trade unions' side, attempts have been made to organize workers employed in new types of activities, such as platform jobs in Italy and France.

\section{BOX 1.1 SCOPE OF THE RESEARCH FOR TOPIC 1}

This research is intended to gain an understanding of what policies and measures can help to enhance the social partners' representativeness and capacity to play a role at the national level. This includes, for instance, an analysis of the incentives or barriers for workers or companies to join trade unions or employers' organizations. Also relevant are initiatives taken by the social partners to reach out to new members, to offer new services and to maintain and continue to serve their membership in order to shape the future of work. This thematic research was to try to identify the conditions that may empower the social partners and help them to figure more prominently in labour markets and in the world of work. Issues of responsibility and trust may also be explored. 
As noted in Chapter 3, the decline of union density has been particularly marked among young, low-skilled workers, those on short-term contracts and those who were foreign-born. In Sweden, for instance, and in order to counteract the reduction of youth membership, some trade union federations decided to launch information campaigns at school level, and to launch a campaign targeted principally at students and young academics, while others have opened membership to the self-employed and students. In Croatia and Slovenia, for example, both trade unions and employer organizations have implemented programmes to promote the attraction and retention of members by increasing the quality of services and by providing a number of new legal services. In France, the trade unions have also developed new forms of digital support and services, and online communities.

Similarly, in Italy the trade union confederations have been implementing strategies to increase membership, targeting categories such as young people, workers in atypical employment and migrants. These strategies include both organizational measures (creation of specific departments or committees) and policy initiatives intended to increase recruitment. Innovative services are now being provided in relation to unemployment and pensions, work-related grievances, tax obligations, occupational training, welfare and health measures, but also tourist or travel packages, supermarket discounts and special insurance packages.

For its part, the employers' organization Confindustria has adopted a strategy with greater emphasis on service provision, using marketing techniques and recruitment targets assigned to territorial structures in order to expand its membership in relation to small firms.

In Greece, the four representative national employers' organizations recognized the need to expand their membership by enlarging their membership services, including legal advice, training and group insurance schemes. The General Confederation of Greek Workers (GSEE) also acknowledges this need, especially in relation to young people.

In Poland, trade unions have resorted mainly to conventional recruitment methods, using activists to reach out to workers at workplaces. In France, workers' and employers' organizations have developed practical guides to help their members adapt to the new rules of representation at the workplace, especially social and economic committees.

In Ireland, several unions - including the largest union, the Services, Industrial, Professional and Technical Union (SIPTU) and the retail workers union, MANDATE, and Forsa, the public sector union - have established organizing departments to increase membership, including targeting particular groups, such as young people and immigrants, in specific sectors (for example, hotels).

In countries with low trade union and employer organization membership, such as the Baltic states (see Chapter 17 in this volume), the social partners have also implemented specific programmes. For instance, in Estonia the trade union confederation (EAKL) has developed an action plan to increase its membership using various means, such as analysis of jobs and sectors that are not yet unionized and specific actions targeting students in vocational schools. The Estonian Employers' Confederation (TKL) has successfully implemented a strategic plan intended to diversify its membership, with a special focus on information technology (IT) companies, both large and start-up, and firms that are representative of the new economy. 
The membership and attractiveness of social partner organizations are also influenced by the overarching industrial relations environment and their capacity to shape labour market outcomes through social dialogue and consultation processes. Therefore, the project also analyses what opportunities social partners have to play an active role in the governance of the world of work, including through collective bargaining, consultations on social and labour policies, and participation in labour market institutions.

Chapter 2 reveals that such capacities of the social partners vary across EU member states. Also, it illustrates that national industrial relations systems (including predominant level of collective bargaining, coordination and articulation between levels, scope of agreements, and the respective role of the state/public authorities in regulating the labour market) affect the extent to which collective bargaining regulates working conditions. In Belgium, the support of the two sides of industry for a highly centralized and strongly coordinated multiple-employer bargaining regime explains the high collective bargaining coverage rate. Similarly, in Spain there is effective articulation between the various levels of collective bargaining, which also explains the resilience of the Spanish industrial relations system. The existence of extension mechanisms, according to Chapter 2, also may have played a role in maintaining a high union density and high employer affiliation rates in Belgium, as in the Scandinavian countries, which frequently apply extension mechanisms. This seems to have increased the social partners' impact on labour market regulations (see Chapter 3). Also, the extension mechanisms might lower the willingness of social partners to engage in autonomous social dialogue at local level and to sign collective agreements (see Topic 2). As highlighted in Chapter 2, only powerful employer organizations and trade unions with a large membership can guarantee social partner independence, and their capacity to regulate the terms and conditions of employment, and influence policies affecting the world of work. The high collective bargaining coverage in Italy and Spain are owed mainly to their willingness to conclude collective agreements at industry level.

The effective involvement of employers' and workers' organizations, together with government, in national tripartite social dialogue and high-level partnership and negotiations also represents an important tool that enables social partners to influence decision-making and policy formulation and implementation, thus enhancing their legitimacy, strength and representation structures at lower levels (Molina 2008); and even more so if the partnership and negotiations lead to national agreements or pacts that define macro-level guidelines and policy objectives, as well as directions for lowerlevel initiatives in relation to the governance of the world of work. As a recent example, in the context of the Covid-19 pandemic, national tripartite consultations and agreements set the stage for lower-level bipartite social dialogue and negotiations (sector and enterprise levels), for example, in the Czech Republic, Denmark, France and Italy (see Box 1.2).

However, tripartite social dialogue can be less effective if it is too formal and does not foster concrete negotiations and outcomes at lower levels. For instance, in many central and eastern European countries, tripartite social dialogue and bodies that often generated tripartite agreements and sometimes served as a basis of for collective agreements, concluded subsequently at the industry and company level (as in Hungary and, to some extent, in Romania) and have progressively become merely advisory and relegated to consultative processes with less impact on macro and labour market policies 


\section{BOX 1.2 ITALY}

A tripartite 'Joint Protocol for the regulation of measures to combat and contain the spread of Covid19 at the workplace' was signed on 14 March 2020 between the Government and the social partners. The Protocol is to be implemented in all companies and workplaces involving the participation of workers' representatives.

The Protocol contains 13 action points, including social safety nets, smart working arrangements and overall measures aimed at maintaining economic activity, while ensuring a safe working environment. It also calls upon the social partners to further specify these measures by industry/ sector. Questions such as paid leave are to be the subject of collective bargaining. On this basis, on 24 March 2020, following trade union demands, Italy's banking sector employers and trade union associations signed a new collective agreement containing measures tailored to the needs of banks and their employees, such as on opening hours and customer appointments. Furthermore, several companies and trade unions have concluded agreements on a number of measures related to temporary closure of plants, suspension of production, and the like.

Source: ILO (2020) and TUAC, the latter accessed 1 June 2021 at https://tuac.org/news/covid19-crisis-map ping-out-trade-union-and-social-partners-responses/.

(Eurofound 2019). The chapters in this volume show that social partners in a number of central and eastern European countries and in the Adriatic region see the potential to improve the functioning of tripartite social dialogue bodies and consultation processes so that they could have a real impact, which would also lead to greater involvement of social partners in decision-making.

\subsection{Topic 2: Supporting Social Partner Autonomy}

This topic was motivated by the social partners' concerns that insufficient room was left for the development of autonomous social dialogue, notably owing to over-intervention by the state, including excessive legislative provisions. As explained by Bernd Waas in Chapter 3 of this volume, both international and European law contribute to protecting and guaranteeing the social partners' autonomy. The value of autonomous social dialogue between workers and employers and their respective organizations has been underlined by the Organisation for Economic Co-operation and Development (OECD 2019), according to which the quality of the working environment appears to be higher in industrial relations systems with powerful and autonomous social partners, associated with high collective bargaining coverage. Despite the challenges facing the social partners in many countries owing to the decline in membership and the undeniable difficulties facing collective bargaining, as documented in Chapter 2 and in most country reports in this volume, autonomous social dialogue and collective bargaining remain a flexible instrument that could play an important role in helping enterprises and workers adapt to the changing world of work (OECD 2019). While claiming their autonomy, however, the social partners agreed that government had an important role to play to provide the necessary framework and thus to stimulate autonomous social dialogue. However, as highlighted by many ministers in this volume's foreword, the government can either foster or hinder autonomous social dialogue, depending on the nature and focus of its intervention in industrial relations. 


\section{BOX 1.3 SCOPE OF THE RESEARCH FOR TOPIC 2}

This research is to assess what 'space' is left or created by government, regulations and social dialogue institutions for the social partners to shape working conditions autonomously, including by bipartite social dialogue and collective bargaining at national, sectoral and company levels. Some social dialogue practices will be analysed, such as social dialogue institutions (for example, social and economic councils or specific bodies, for example, concerning OSH [occupational safety and health] or vocational training), tripartite agreements and other institutions (including extension mechanisms, derogation clauses), as well as their respective impacts on social partner autonomy.

This topic is very much related to the first topic in that increased room for autonomous social dialogue can help the social partners to expand the scope of their intervention, enhance their legitimacy and improve their attractiveness to potential new members.

The thematic chapter that covers this issue (Chapter 3) discusses the respective pros and cons of three types of mechanisms for further developing autonomous social dialogue. First, extension mechanisms ${ }^{3}$ (which allow extension of the benefits of an agreement to enterprises or workers that originally were not among those signing the agreement; and add the possibility of derogating by collective agreement from the law): while these mechanisms can help to extend the coverage of collective agreements and thus somehow compensate the possibly declining influence of trade union's presence in all individual sectors and enterprises, as we saw for topic 1, they do not incentivize those same organizations to increase their sphere of influence in order to be able to sign agreements at all levels. They may thus hamper recruitment of new members in the long run. There is also the argument that is put forward, for instance, in the chapters on Poland and France that erga omnes clauses do not encourage workers to join trade unions since they already benefit from collective agreements signed by the unions. The second mechanism is derogation clauses (which allow parties signing a lower-level agreement to agree on standards or conditions that may be less favourable than the original upper-level agreement): while negotiations on these derogation clauses may stimulate social dialogue and collective bargaining at the lower level, particularly to match local conditions, they may also be counterproductive because they undermine the upper-level autonomous agreement that was concluded by social partners in the first place and thus erode members' trust in these organizations and in their capacity to ensure the implementation of agreements they sign.

Finally, as explained by Waas in Chapter 3 in this volume, the tripartite institutions and agreements that exist in many European countries - involving the government, and national confederations of trade unions and employers' organizations - may also influence autonomous social dialogue in different ways. By providing a more general framework, they can, first, encourage decentralized negotiations and collective agreements to implement the framework. This can result in a type of virtuous relationship as national tripartite agreements could be complemented by sectoral, regional and enterprise collective agreements. The feedback from this decentralized social dialogue and negotiations can then provide useful elements for enriching and improving the national social dialogue processes and frameworks. Second, tripartite institutions and agreements can provide the social partners with an opportunity to participate in the decision-making process, and 
thus influence national policies on, for instance, the labour market or social protection, pension reforms, skills policies and so on. This can then give them legitimacy for autonomous social dialogue at more decentralized levels. Also, it can further enhance the social partners' role and zones of influence, which can then be a driver for higher membership and help the social partners to become more representative at local level. In a number of countries, tripartite institutions have separate sub-bodies where bipartite social dialogue takes place and where the social partners agree, for instance, on joint recommendations or plans of action that they then bring to government's attention or enshrine in a collective agreement.

However, if tripartite mechanisms are unable to produce positive outcomes or allow the social partners to exercise real influence on public policies and reforms, they can have the opposite effect. That effect is the weakening of the social partners' capacity and legitimacy as regards autonomous social dialogue, while also generating a general disillusion among members who expect improvements in their daily working and living conditions as a consequence of the participation of the social partners in tripartite mechanisms.

As for extension mechanisms, tripartite institutions and agreements can lead the social partners to concentrate their resources to exert influence at the national level, while investing less in their capacity to engage in autonomous social dialogue at lower levels. Government interference in autonomous social dialogue can also play a role. The last financial and economic crisis saw multiple instances of this type of government interference, for instance, in Greece, Romania and Spain, with unilateral decisions by public authorities on the regulation of collective bargaining (for example, the renewal of collective agreements and decentralization of collective bargaining, notably in Greece but also in Romania) and on the reform of industrial relations systems in general. This can restrict social partner autonomy: in Greece, for example, there was a 75 per cent decline in collective bargaining coverage, ${ }^{4}$ while in Romania, the coverage fell from 100 per cent prior to 2011 to around 23 per cent in 2016 (chapter on Romania in this volume). As shown in the chapter on Poland, detailed regulations are often perceived by social partners, in particular employers, as a factor limiting collective bargaining. In Latvia, both the Confederation of Employers (DDK) and the Free Trade Unions Confederation of Latvia (LBAS) are keen to achieve more agreements in different sectors, a desire seemingly thwarted by the over-regulation of the labour market, according to the DDK. This is in contrast with the situation in Sweden where a significant space is left to social partners by the legislator, which led to the development of a strong bipartite social dialogue and a number of bipartite agreements.

Not all state interventions are counterproductive and restrict autonomous social dialogue. On the contrary, when these interventions are appropriate and timely they can boost collective bargaining, as shown by the Labour Ordinance No. 2017-1385 of 22 September 2017 on collective bargaining in 2017 in France, which opened up a new space for company agreements on, for instance, teleworking. Other examples are the change in the labour law on overtime in Latvia that enabled the social partners to sign the first collective agreement in the construction sector, and the law (No. 81/2018) on the regulation of teleworking in Romania, which helped to promote collective bargaining in relation to digitalization, as shown by the agreement on occupational training concluded by the social partners in the banking and insurance sector. One objective of the latter 
agreement was to enhance employees' ability to use remote working and collaboration by means of digital tools (see the chapter on Romania, in this volume). In Germany, the government is planning to introduce an opening clause for the Working Time Law to allow the social partners to test innovative and flexible working time models to cope with the extensive changes triggered by digitalization. The example of Germany is interesting because the state has implemented a series of measures to counteract the decline of multi-employer bargaining (see the chapter on Germany in this volume). The government can also encourage autonomous social dialogue through the reflection of outcomes of bipartite agreements in legislation or other policy measures. For instance, in Belgium the government supported the implementation of the content of the 2017-18 inter-professional agreement intended to improve sustainable mobility (Eurofound 2019).

These three social dialogue mechanisms are thus not neutral in terms of social partners' capacity and legitimacy in developing autonomous social dialogue. This may explain why the social partners sometimes disagree on the direction and position to be taken on these mechanisms, for instance extension mechanisms. In this regard, we supplemented the thematic and country reports with a survey to collect social partners' opinions about the effectiveness and impact of national social dialogue institutions, including their capacity to stimulate autonomous social dialogue. The results are presented in the final section of this chapter.

\subsection{Topic 3: The Role of the Social Partners in Relation to Digitalization}

The social partners play an increasing role in addressing the potential employment effects (on both the level and structure of employment) brought about by the digital revolution and a possible substitution of labour by capital. This can take place, first, at the macroeconomic level, notably through tripartite social dialogue to discuss issues, such as the macroeconomic strategy, industrial policies, tax policies and pension reforms, skills policies, active labour market policies and so on, and then at the micro level, with the discussion of work reorganization and production processes - including restructuring and downsizing - at the firm level. In this respect, interesting initiatives have been launched by the social partners in Sweden and Germany to address the digital revolution, such as Industry 4.0 or digital agendas, followed by firm-level discussions and negotiations.

In the past few years, EU-level social dialogue has been rich, involving social partners in individual sectors making statements on the impact of digitalization on the economy, for instance, for insurance, banking or chemicals (see Table 4.3 in Chapter 4 for the whole list). At cross-industry level, digitalization was included as one of the six lines of work of the European Social Dialogue Work Programme 2019-2021. As a consequence, a European framework agreement on digitalization was concluded in March 2020 whose clauses are to be implemented at national level. No doubt this framework agreement will feed and stimulate the social partners to conclude more specific agreements at national, sectoral and firm level in individual countries.

Skills upgrading and reskilling through training for the digital economy is also a need that the social partners help to meet, for instance, by being involved in the policy discussions and decisions on the forms and funding of these training policies and programmes. 


\title{
BOX 1.4 SCOPE OF THE RESEARCH FOR TOPIC 3
}

\begin{abstract}
While there are many studies on the subject, there is little on the role of the social partners, especially against the background of new questions in response to new forms of digitalization. This thematic research focuses on the role of the social partners in addressing digitalization at company level. Examples of social dialogue practices will be presented in the areas of working time flexibility, worklife balance, upskilling, workers attraction or retention, job transition and working conditions (such as workers' well-being at work and health and safety, including psychosocial risks). It addresses aspects of the digital transformation and digital organization of work, as well as their impact on social dialogue. Online platforms are only one new form of work organization - for the time rather limited - that will also be investigated alongside other trends in work organization and digitalization.
\end{abstract}

They could then take up at a lower level, for instance, the sector of activity and the enterprise on training strategies for restructuring or mobility purposes. Here again, social partner initiatives and policies to foster digital skills and lifelong learning are reported in countries such as Germany, Latvia, Sweden and Denmark.

Another area that some social partners are working on is the growing diversity of forms of employment, including those facilitated by new digital technologies. The emergence of jobs delivering services through platforms, although still accounting for less than 5 per cent of total employment, is an important example as they often involve the splitting of production processes into simple tasks, for example in online services or urban transport or delivery that are carried out by various own-account workers. In some instances, platform workers may share some characteristics of employees and some of self-employed persons, so determining their employment status may not always be straightforward; this has implications for the extent to which they are covered by labour regulations and social protection systems.

The social partners are also reaching agreements addressing labour protection issues stemming from the emergence of these new forms of work that have made it possible to enlarge social protection coverage to workers in digital platforms, as well as to those in temporary employment and dependent self-employed, as we saw for different European countries in previous publications (Vaughan-Whitehead 2018, 2019).

The introduction of new technologies can help the social partners to reduce hazards and better manage $\mathrm{OSH}$-related risks (for example, by using robots for hard and dangerous tasks). Also, new OSH risks that may be brought about by digital technologies, either because of workers' loss of control over the production process, as the speed and order of tasks are decided by digital devices, or owing to increasing anxiety brought on by the uncontrollable work pace and/or reduction of privacy, can also be addressed through social dialogue. The blurring of the division between work and private life and modalities of telework are issues addressed and discussed by social partners. While old health risks may disappear with the introduction of new technologies, new health risks may emerge, such as musculoskeletal disorders (for example, carpal tunnel or tendonitis), fatigue and eye strain owing to excessive or intensive exposure to display screens, or, as explained in Chapter 4 in this volume, new types of risks brought about by the interaction between humans and robots. 
In relation to topics covered, collective agreements that deal with these issues generally include arrangements on telework, or the adoption of new technologies, as in Spain. In Italy, they often concern the occupational impact of digitalization on job destruction and employment shifts. For example, in the Italian postal sector in 2017, a national collective agreement on mobility made it possible to reduce the closure of post offices brought about by the reduction of domestic and international postal services and the shift from letters to digital mail. Other agreements concerned investments in Industry 4.0 , the legal status of digital platform workers, individual and collective rights and protections and the effects of the new information and communication technologies (ICTs) on workers' privacy. Also of note are, for instance, innovative agreements at the territorial level in Italy signed by institutional trade unions, workers' autonomous collectives and the management of a few platform companies in the food industry. They cover minimum wages, working time and other working conditions. Sweden also offers a series of very interesting collective agreements in platform companies in diverse sectors, such as transport and education (see Chapter 4 and the chapter on Sweden in this volume). Interestingly, a number of collective agreements, for instance in Denmark but also in Portugal, are proposing training programmes to better prepare their labour force for digital transformation (again, see Chapter 4). Some collective agreements, for instance in Germany, have also addressed the issue of employee data protection.

We should emphasize that collective bargaining is not the only tool that social partners use to address digitalization. Both trade unions and employers' organizations are involved in various initiatives, for example, monitoring the introduction of new digital technologies and compliance with labour standards, extending their activities to sectors in the new economy, and participating in training schemes and in various committees and advisory groups at different levels of digital innovation. It is interesting to note that digitalization, and the use of IT platforms, represent important leverage for the social partners to extend their activities, increase their sphere of influence and reach new members.

Social partner roles and social dialogue on digitalization differ across European countries. This may also reflect a different level of exposure thus far, to robots for instance, as shown in Chapter 4 in this volume, with around 1300 robots per 10000 workers in Germany and France, compared with only 200 in Poland and other countries. This degree of exposure itself reflects national economic structure: the automobile sector, for instance, is directly affected by robotization. Similarly, the lack of exposure to digitalization in the candidate and potential candidate countries explains why the actions and negotiations of their social partners continue to be focused on traditional issues such as wages and employment.

While providing useful examples of initiatives on the above-mentioned items, Chapter 4 also highlights issues that do not seem to have been dealt with very often. Surprisingly, the representation of new workers related to the digital revolution (freelancers, dependent self-employed and subcontracted workers) seems to be among those. It is interesting to see the format used thus far, with agreements on these issues predominantly at enterprise level, while sectoral bargaining has been used only sparsely.

Collective agreements on digitalization - for instance, in Spain - also seem to prevail in large, multinational corporations operating in highly competitive global sectors, and are rare among small and medium-sized companies. 
In summary, it seems that the social partners are facing a challenge covering these newly emerging issues, sometimes owing to lack of time or of technical capacity within their organizations. In Germany, for instance, it became apparent from the interviews that 'digitalization is exacerbating the overload of works councils' (Chapter 4, s. 3.2.2, in this volume). On the employers' side, we should highlight the low propensity of new digital firms to join traditional employers' associations (see Chapter 4).

The timing seems also to be relevant: Chapter 4 insists that, to date, social dialogue at national level has mainly discussed the consequences of technical change ex post, instead of trying to develop anticipatory measures.

\subsection{Other Topics Reported by National Employers or Trade Union Organizations}

The interviews with national employers and trade union organizations also helped to identify other issues on which the social partners are increasingly active. Labour migration is a topic of increasing interest among the social partners. Trade unions in countries such as Spain and Ireland have launched campaigns to improve immigrants' working conditions.

In Poland, labour migration is a concern for both employers' and workers' organizations, though for different reasons. Both social partners would like the state to create a space for social dialogue and consultation on this important issue for Polish society and the economy. Current challenges include the protection of migrant workers against abuses (the main concern of trade unions) and labour shortages (the main concern of employers' organizations). In Sweden, the social partners took up the issue of the integration of migrant workers and concluded an agreement on this issue.

A number of chapters in this volume - for instance, that on Turkey - also mention the development of global supply chains, that is, which social partners would need more knowledge and a greater capacity to integrate the relevant workers and employers at the different stages of the supply chains in their activities and social dialogue.

\subsection{The Need for a Comprehensive Social Partners' Strategy}

We must emphasize that while the three topics have their own logic and contents, they are very much interrelated in many respects. For instance, the social partners' capacity to attract new members and increase their membership and representativeness (Topic 1) will clearly depend on their success in reaching concrete and effective outcomes through social dialogue, consultative processes and collective bargaining, which boost their legitimacy (Topic 2). The reverse is also true: opportunities to play a stronger role in the governance of the world of work and in shaping labour markets, including on topics such as anticipating, accompanying and monitoring the trends and effects of digitalization (Topic 3), migration, the rapid development of global supply chains, opportunities and challenges brought about by the growing variety of work arrangements increase the capacity of the social partners, and help them retain and attract new members. 


\section{THE ROLE PLAYED BY NATIONAL SOCIAL DIALOGUE INSTITUTIONS: SURVEY RESULTS}

In the interviews carried out within the framework of this project, the social partners often emphasized the role of national social dialogue institutions as platforms for policy concertation on issues of national relevance. They thus provide an important framework for further bipartite social dialogue and collective bargaining rounds at lower levels, namely, the sector, region or enterprise.

To complement the experts' thematic and national reports, we carried out a survey among the national social partners in selected European countries to collect their views on the role and impact of national social dialogue institutions, and their capacity to enable them to respond to the current and future challenges and opportunities brought about by a changing world of work.

The survey targeted the representative employers' and workers' organizations in the 27 EU countries plus candidate and potential candidate countries, making 34 countries in total. We received 41 answers to this questionnaire from both employers' and trade union organizations (22 trade unions and 19 employers). The information collected is interesting. First, it helped us to better understand the complex landscape of these social dialogue institutions, which are generally tripartite in nature and take the form of a tripartite council, committee or board (this format was confirmed by 85 per cent of respondents), and specialized committees, such as on vocational training, wage setting and health and safety issues (reported by 86 per cent of respondents) (see Figure 1.2).

In a number of countries, there are also social dialogue institutions that are more bipartite in nature, omitting the government (reported by 39 per cent of respondents). While the social dialogue institutions are generally composed of the three main sides (the

What is (are) the major social dialogue institution(s) in your country at national level?

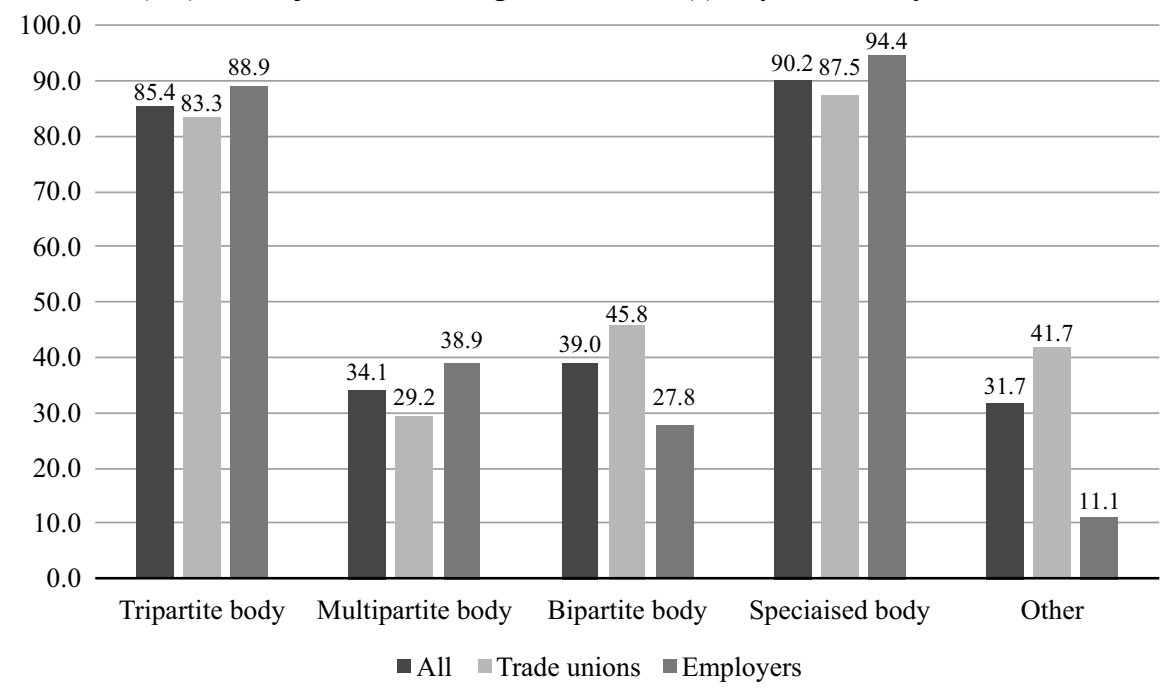

Figure 1.2 Major social dialogue institutions 
government, trade unions and employer organizations), they have also been extended in some instances to other organizations, for instance, those from civil society (reported by 36 per cent of respondents). The feedback from trade unions and employers was similar, because they both selected tripartite bodies and specialized committees as the prevailing institutions of social dialogue at national level, with the slight difference that a higher percentage of employers reported tripartite and multipartite bodies, while a higher percentage of unions reported bipartite social dialogue, as did other institutions, such as the social security management committee in Belgium, the Medical Insurance Council in France, the Work-related Accidents Fund in Greece, sectoral committees in Poland, ILO councils (as in Sweden or Hungary) or social and economic councils (Luxembourg, Italy and others).

We then asked respondents to report how much they felt that these institutions allowed them to be involved and exert influence on a number of issues. Figure 1.3 summarizes the results, and highlights their feeling that these institutions mainly helped them to be fully or largely influential (58 per cent in total) in areas such as social dialogue and collective bargaining. Other topics include social protection (unemployment, social security and pensions) and health and safety issues (47 per cent reporting a large or full influence), thanks to a number of specialized tripartite committees on these issues. Wages are another traditional area in which tripartite institutions help social partners to make themselves heard (43 per cent rated this influence as substantial), and in particular the adjustment of the statutory minimum wage. More recently, the social partners have increasingly been involved in labour market policies and regulations, over which 43 per cent of respondents declared that they have a big influence, with 40 per cent claiming a big influence over skills development and training programmes.

Do you feel such institution(s) allow your organization to be involved and be influential in decision-making on the following issues?

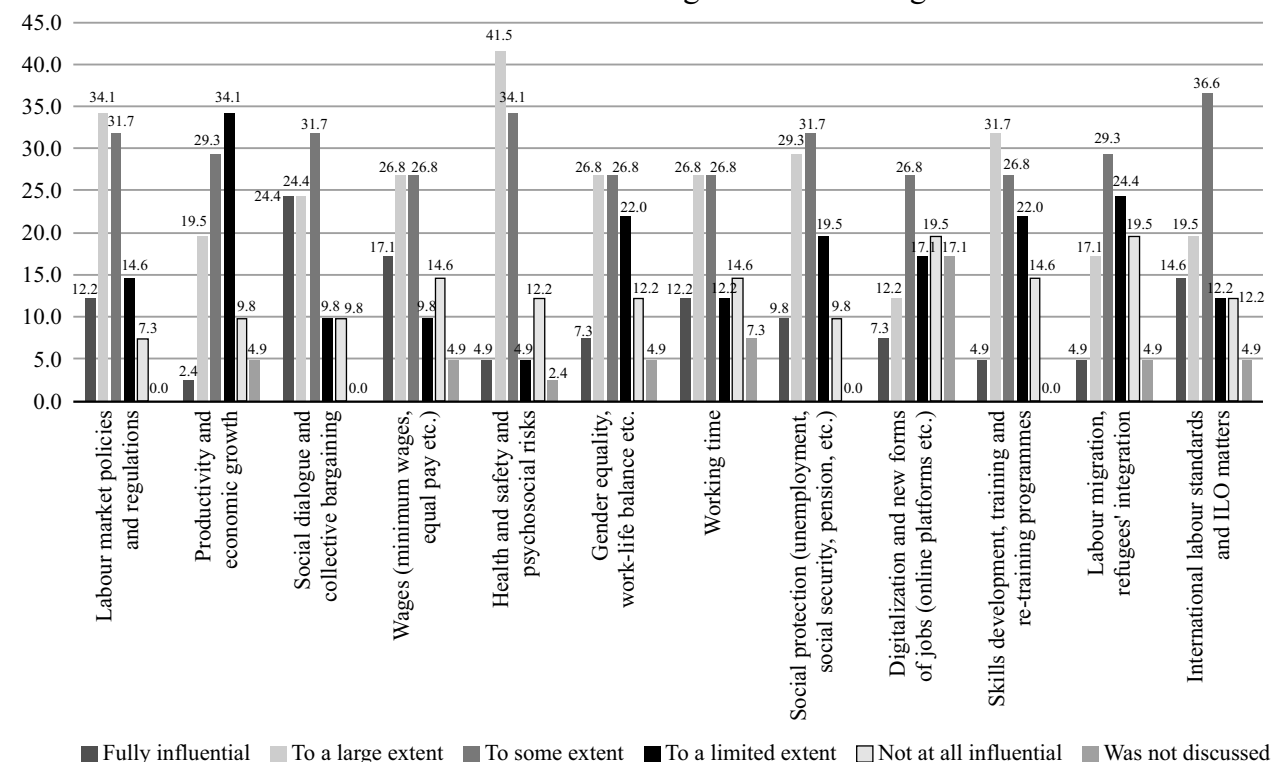

Figure 1.3 Issues on which social partners report having most influence 
The influence of these social dialogue institutions was also rated as important by at least 40 per cent of respondents in areas such as gender equality and work-life balance, as well as working time.

Social partners have different perceptions of the areas in which this social dialogue allows them to obtain more influence: for employers' organizations, it is mainly in the areas of productivity and economic growth, skills development and also gender equality, while trade unions look more favourably on national social dialogue institutions to cover issues related to health and safety, wages and collective bargaining. They both reported that these social dialogue institutions enable them to influence labour market policies and regulations, as well as social protection.

Surprisingly, these institutions were felt to be less effective in the areas presented in this volume as posing challenges to the social partners. As an example, only 20 per cent of respondents felt that these social dialogue institutions were allowed to play a substantial role in decision-making on digitalization, while 40 per cent responded that social dialogue was not at all (or only to a very limited extent) influential in respect of digitalization. An additional 20 per cent of respondents also reported that this topic has never been addressed by social dialogue institutions. Perhaps in some countries there is no integrated discussion on digitalization itself but instead on specific policy areas in which digitalization may then be addressed.

Similarly, only 25 per cent reported that they were significantly involved in labour migration issues, while more than 45 per cent reported no, or only limited, influence on this topic. Less than 20 per cent felt influential on issues such as productivity and economic growth, an issue repeatedly put forward by employers' organizations. On the contrary, 50 per cent reported that they were not influential on this topic.

Another way to evaluate the effectiveness of social dialogue institutions is to look at their possible outcomes. In this respect, there were mixed results (Figure 1.4). On the one hand, a majority of respondents (nearly 70 per cent) reported that the main outcome for them was to obtain shared information, or to be part of a discussion and to have their views heard (66 per cent), but without much influence on decisionmaking. On the other hand, nearly 50 per cent of respondents reported that these social dialogue institutions were giving them the opportunity to influence legislation (new or amended) and policies. For nearly half of them, it was also a way to reach a consensus through the conclusion of agreements (36 per cent) or the drafting of joint recommendations, opinions or reports (for 37 per cent). Also, the influence of social dialogue institutions was evaluated as much lower in respect of ensuring the joint monitoring of these agreements (only 29 per cent), and of less value for bringing about training of members or developing the organization's internal expertise and technical capacity.

Slight differences were observed between employers' and workers' representatives. A higher percentage among trade unions reported that social dialogue enabled them to obtain or share information or to have their views heard ( 75 per cent among trade unions compared with 55 per cent among employers); trade unions also reported the ability to negotiate agreements ( 37 per cent among trade unions and 27 per cent among employers). Conversely, a higher percentage of employers (50 per cent compared with 45 per cent among trade unions) reported that it frequently enabled them to influence new or amended legislation. 
Did your participation in social dialogue bodies (institutions) generally allow your organization

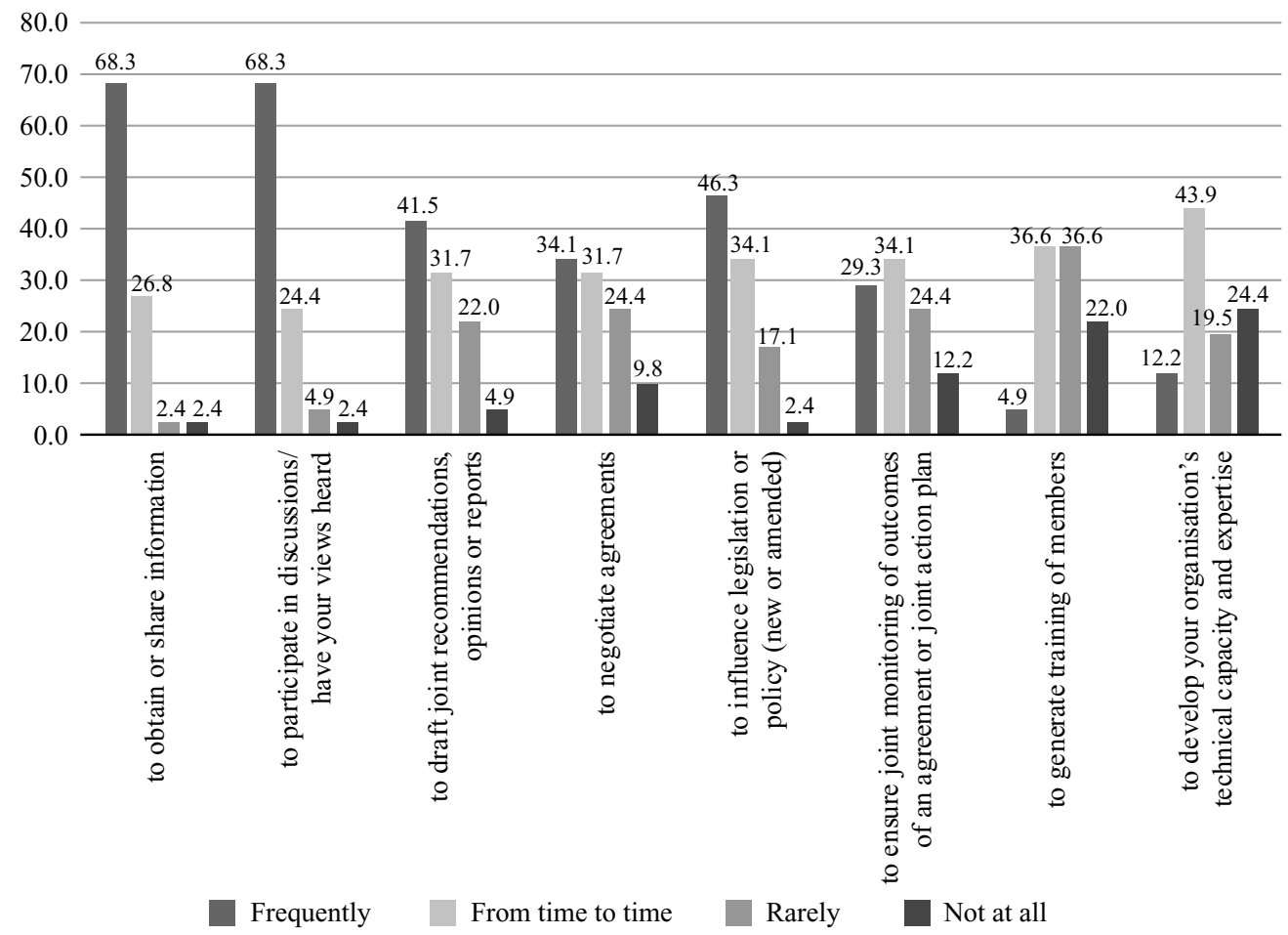

\section{Figure 1.4 Outcomes from national social dialogue}

It was also revealing to ask social partner organizations what benefits their organizations derive from their participation in social dialogue institutions (Figure 1.5). The main benefit they reported was to increase their legitimacy, together with their public profile (reported by 40 per cent). Thirty-seven per cent reported that one main benefit was to 'raise new and emerging issues', thus confirming the potential role to be played by these institutions in addressing the newly emerging challenges and opportunities in the world of work. Only 23 per cent reported that it helped to solve concrete issues. The results were also mitigated as regards the stimulation of autonomous social dialogue between employers and trade unions (a large influence was reported by only 22 per cent of respondents) and for the conclusion of collective agreements at lower level, sectoral, regional or enterprise (reported by only 20 per cent).

When questioned about the benefits for their own organization, trade unions were found to benefit more in terms of legitimacy, while national social dialogue seems to be more beneficial to employers than to trade unions in increasing their membership, albeit with considerable variance by country. A significant percentage among both types of organization (nearly 70 per cent) reported that social dialogue helped them to solve real issues. Trade unions were more convinced than employers of the capacity of social dialogue to address new issues (48 per cent of employers and 87 per cent of trade unions) or 
What benefits does your organization derive from its participation in this (these) 60.0 institution(s) and to what extent? Could you provide some examples?

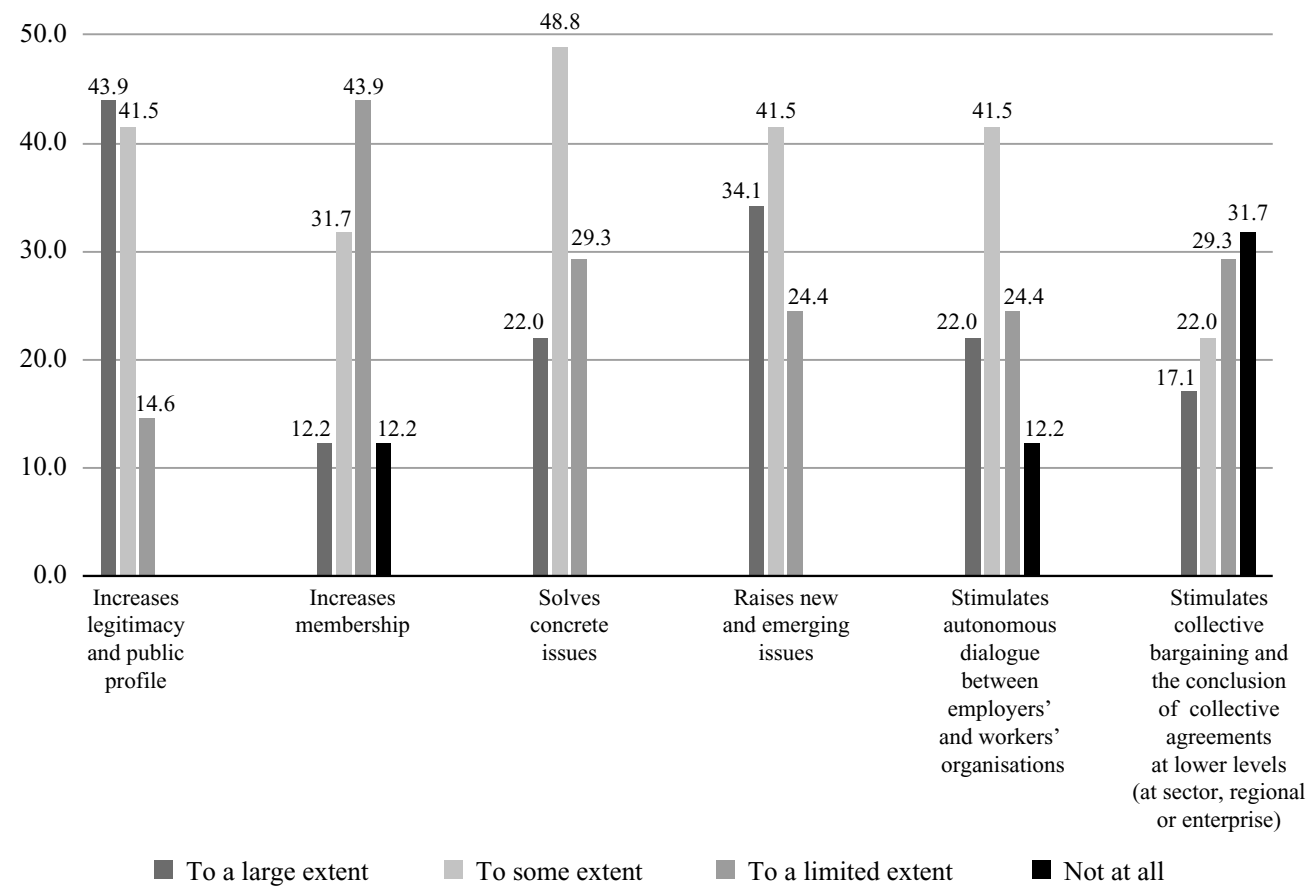

\section{Figure 1.5 Organizational benefits for social partners}

to stimulate autonomous social dialogue ( 75 per cent of trade unions compared with 50 per cent of employers' organizations) and collective agreements at lower level (46 per cent compared with 33 per cent).

This would suggest a need to strengthen the effectiveness of national social dialogue institutions to encourage autonomous social dialogue and would confirm the need for the government to stimulate autonomous social dialogue, as concluded in section 3.2.

This requires some changes in the way social dialogue institutions operate. Through our survey, we tried to obtain inputs from the social partners about the evolution of social dialogue institutions over the past few years and about the direction they believe these institutions should be taking.

First, it is interesting, and hopefully the sign of some dynamic movement, to observe that 37 per cent of respondents reported that their participation in these organizations has increased over the past two years, compared with 45 per cent who reported no change, and only 17 per cent who reported that their participation had decreased (Figure 1.6).

However, this outcome of increased, unchanged or decreased participation was the result of a voluntary decision for only 28 per cent of respondents, while it was owing to the government's action for 54 per cent of them (Figure 1.7). This means that the 
Has the participation of your organization in this (these)

60.0 institution(s) over the last two years:

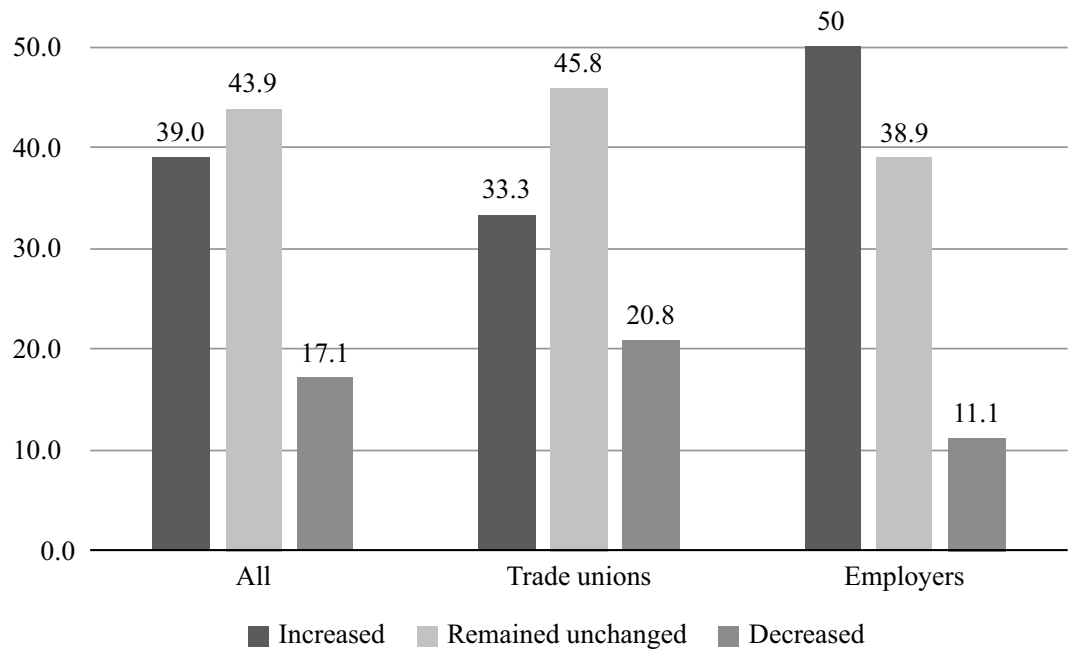

Figure 1.6 Trends in social partners' participation in national social dialogue institutions

If it increased, decreased or remained unchanged, was it following: (multiple answers possible)

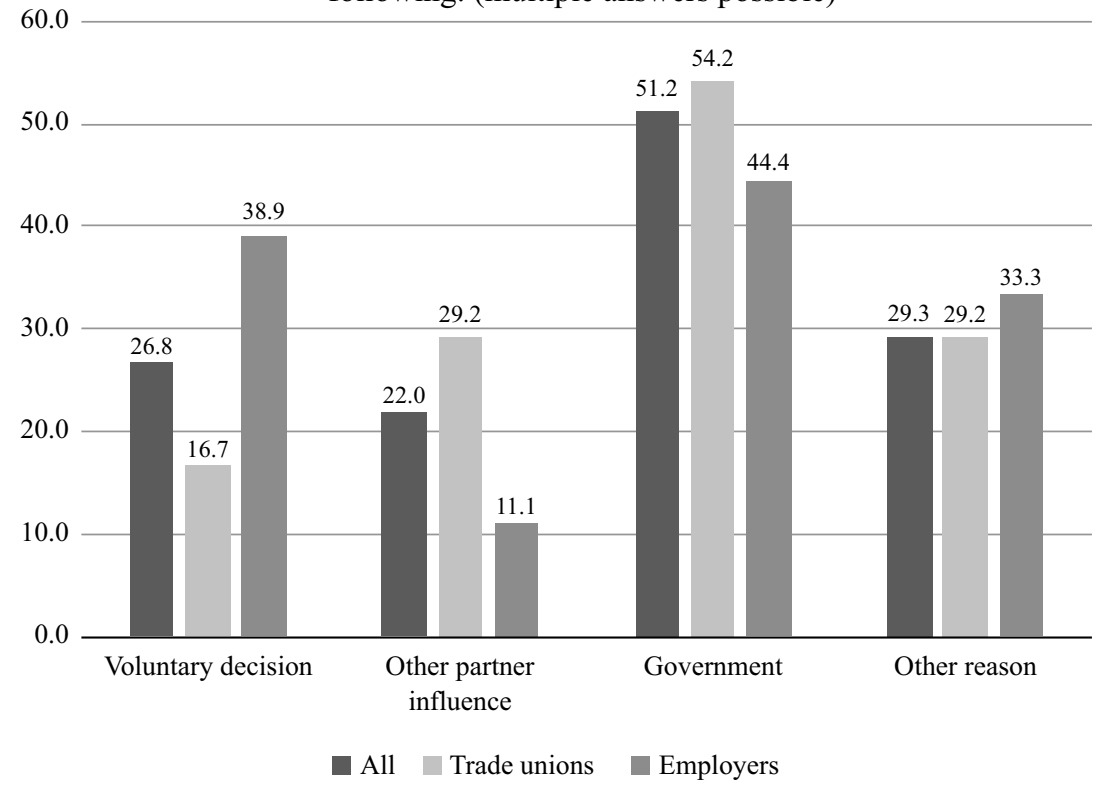

Figure 1.7 Reasons behind social partner participation trends 
government could play a positive role if it fostered increased social partner participation in these institutions (as seems the case for a majority of countries). Conversely, it could play a more restrictive role if it decided to reduce social partner influence and participation in these social dialogue institutions.

The employers reported that they had increased their participation in these social dialogue institutions more than trade unions had (50 per cent of employers' organizations reported an increase compared with 33 per cent of trade unions), while more trade unions reported that they had not changed or had even decreased their participation (21 per cent of trade union organizations compared with 11 per cent of employers' organizations).

The reasons behind these changes are also revealing. For 39 per cent of employers this type of change was a voluntary decision, but was so for only 17 per cent of trade unions. Around 29 per cent of trade unions reported that their decision to participate in national social dialogue institutions had been influenced by the other partner's behaviour (11 per cent of employers' organizations) and 54 per cent reported that this decision was influenced by government behaviour, a feeling also echoed by 44 per cent of employers. The attitude of the government towards social partners' involvement in national social dialogue institutions is thus a key aspect that we further address in this volume.

When asked about how well adapted they believed these social dialogue institutions were to current and emerging issues in the world of work, the results were mixed (Figure 1.8). While 22 per cent of social partners believed all current national social

Do you think the above institution(s) is (are) well adapted to address current and emerging issues in the world of work? 120.0

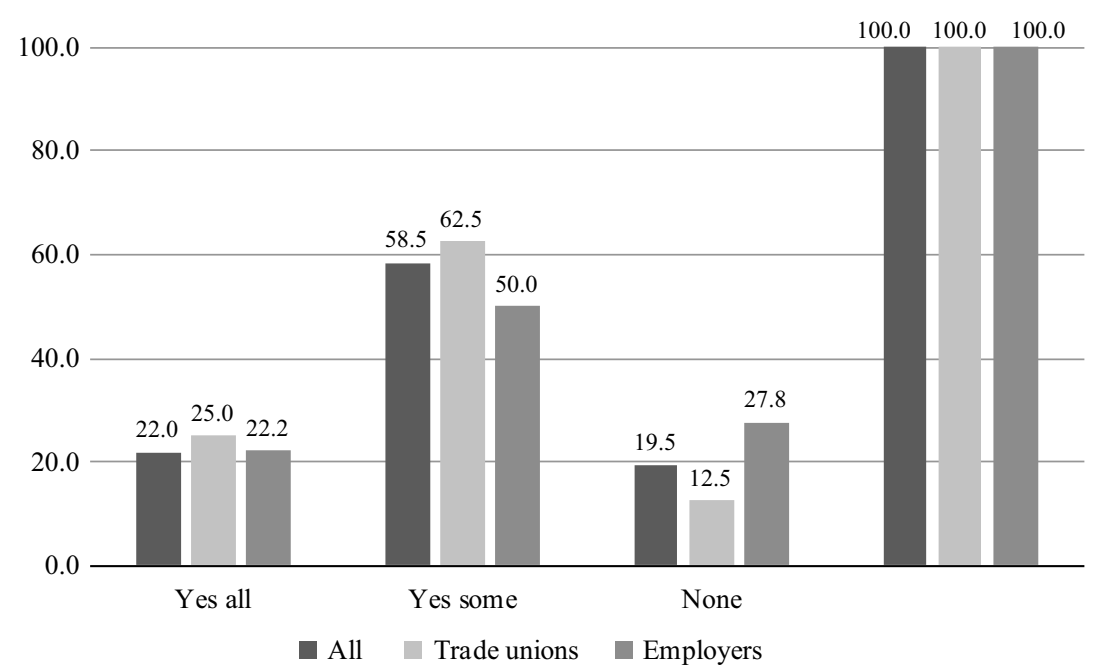

Figure 1.8 National social dialogue institutions' ability to address emerging issues in the world of work 


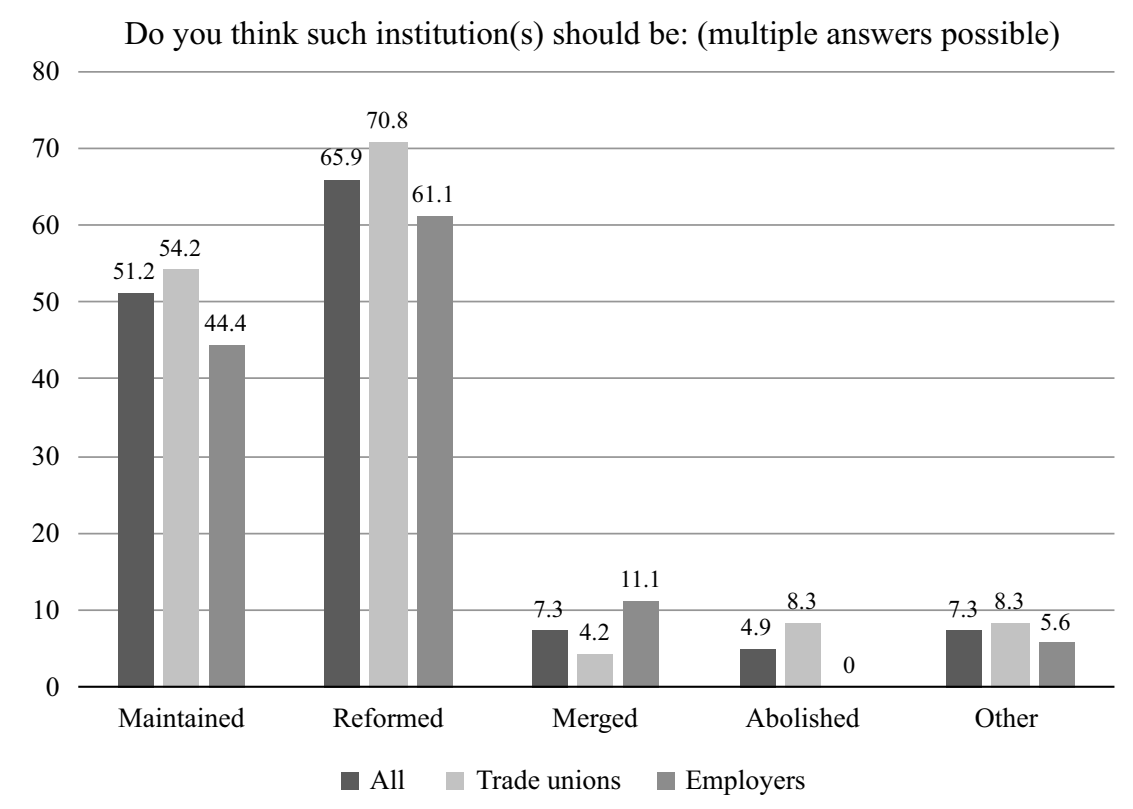

Figure 1.9 Social partner views about the possible evolution of national social dialogue institutions

dialogue institutions were well adapted, 59 per cent reported that just some of them were adapted to address such challenges in the world of work, with nearly 20 per cent reporting that none of them were up to this task, with a higher percentage among employers (more than 25 per cent of them compared with 12 per cent of trade unions). On the positive side, more than 75 per cent of both trade unions and employers believe that all or some of these institutions are adapted and fit for purpose in the context of the future of work.

While a majority (64 per cent) believe that such national social dialogue institutions should be maintained (Figure 1.9), more than 70 per cent also believe that they should be reformed, a percentage this time higher on the trade unions' side (71 per cent compared with 61 per cent among employers). Less than 5 per cent reported that these institutions should be abolished. Participants agreed that there was a need for a general evaluation of all these social dialogue bodies and how they function.

The respondents also indicated what the priorities should be for improving these institutions (Figure 1.10): in their technical capacity (66 per cent), in their mandate and scope of competences (62 per cent), in their method of functioning (61 per cent) and in their funding (reported by 54 per cent). Nearly half of the respondents also expressed the need to discuss the current composition of such institutions. Differences were observed between the social partners: priority areas to be reformed for employers include the 'technical capacity' of these institutions (61 per cent of employers), and their 'mode of functioning' (56 per cent), while the unions highlighted the 'mandate' of these organizations' (54 per cent of them; they generally believe these mandates should be extended), their 'technical capacity' (as employers), but also their funding (33 per cent 
What elements do you think need to change to make this (these) institution(s) more effective? (multiple answers possible)

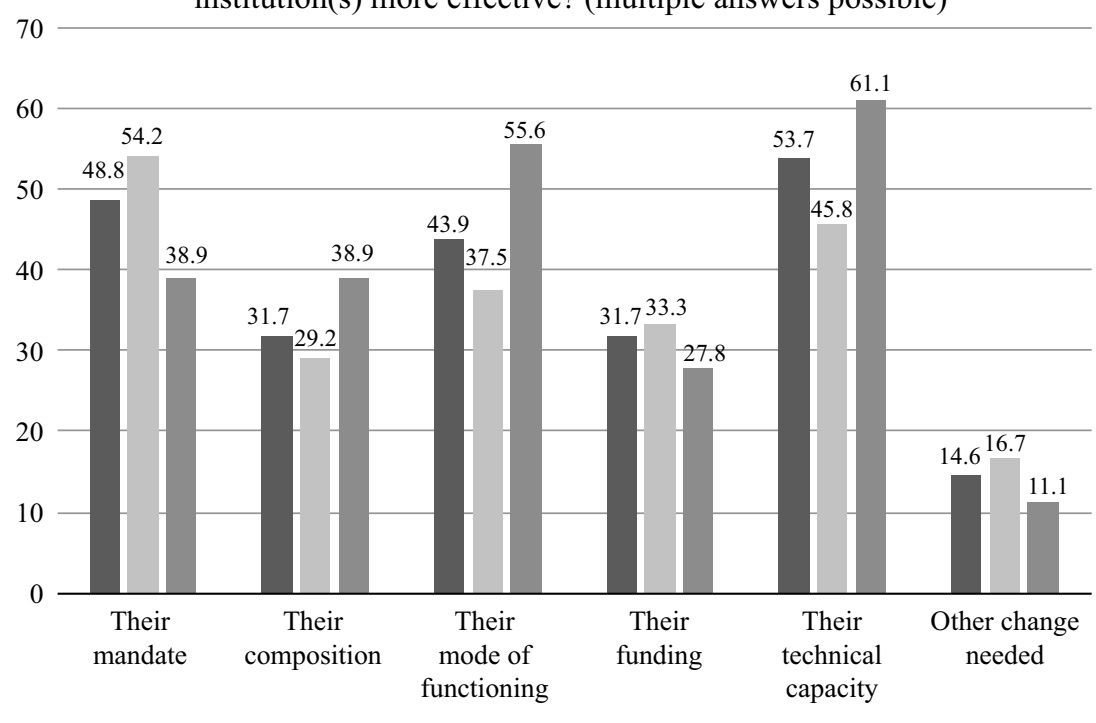

$\square$ All Trade unions $\square$ Employers

Figure 1.10 Directions in which national social dialogue institutions should be evolving

In case you think such institution(s) should be reformed, do you believe specific efforts should be channeled towards: (multiple answers possible) 70

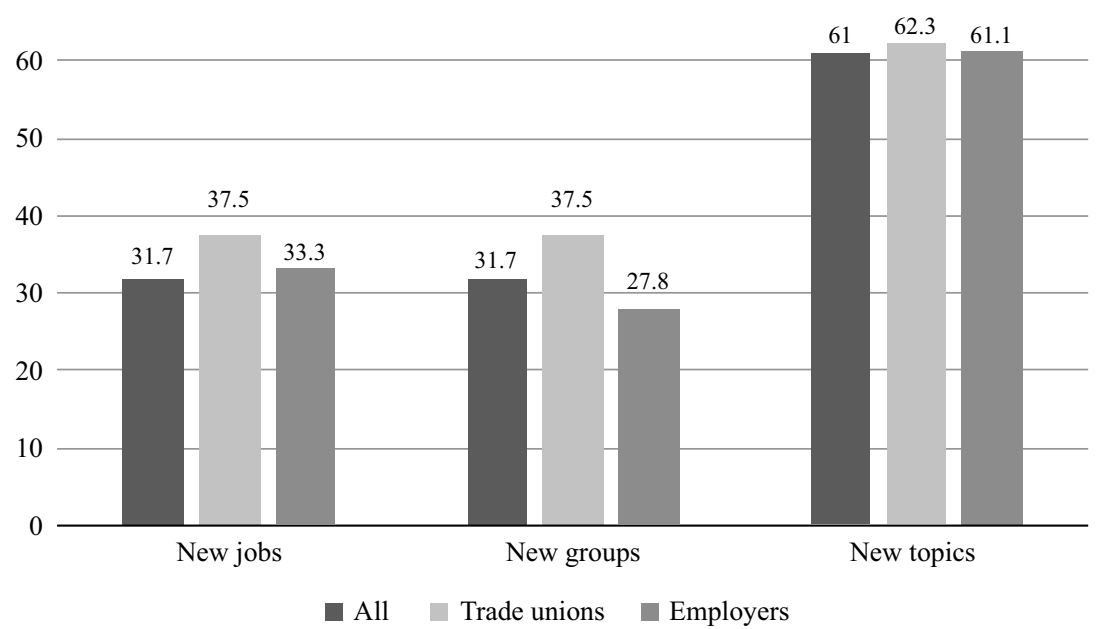

Figure 1.11 Possible directions of reform of national social dialogue institutions 
of trade unions compared with 28 per cent of employers selected this category). Around one-third of respondents, both employers and workers' representatives (39 per cent and 29 per cent respectively), agreed on the need to reform the 'composition' of these institutions.

A clear majority of both trade union and employer organizations (60 per cent on both sides) agreed on the need to enlarge the range of topics addressed by these social dialogue institutions, notably to include new issues in the world of work, but also issues related to the country's general situation (climate change, demography, enterprise sustainability and macroeconomic policy) (Figure 1.11). Although this was not covered in the survey, these institutions can also play an important role in addressing the effects of the Covid19 pandemic, which has hit European countries hard. Nearly one-third of respondents (31 per cent) also reported the need to have these institutions better cover new types of jobs and enterprises; another 31 per cent highlighted the need to have the concerns of new groups better represented in these institutions, such as young people, the disabled, the self-employed, migrants and others.

\section{POLICY CONSIDERATIONS}

In this introductory chapter we have presented some of the comparative inputs provided by individual thematic and national chapters concerning how to enhance the social partners' role in the new world of work. The experts' analyses, based on systematic interviews with representatives of national employers' and workers' organizations, as well as the government (generally the Ministry of Labour), often agree on the challenges and opportunities faced by social dialogue and the social partners in the changing world of work. The three items originally selected by the social partners turned out to be at the core of their current priorities. First, strengthening representativeness and increasing their membership, and within the same process, extending their sphere of influence in respect of labour market regulation and other working conditions-related issues. There were various answers to these challenges, depending on the relevant industrial relations system. Similar initiatives have been attempted by employers' and workers' organizations, as reported by the experts in this volume. Trade unions in a number of countries have put new mechanisms in place to reach new workers, such as the self-employed, those in new forms of employment and workers involved in platform services, but also migrant workers and, more systematically, young workers, with a series of activities at school or university level. On the employers' side, attempts have been made to recruit new members from small and medium-sized enterprises, including start-ups, and employers in the rapidly growing sectors of the economy, for example, IT and new technologies. Both employers' and trade unions' organizations have tried to improve the quality of their services and extend them to new areas, including through digital services.

Second, the social partners confirmed the need for sufficient space for autonomous social dialogue, and in this volume a series of mechanisms are studied in detail, such as extension mechanisms, derogation clauses and tripartite institutions and agreements. The idea is to better identify the extent to which, and how, they contribute to stimulating social dialogue and collective bargaining at different levels. In this respect, the role of governments is also studied, to better understand how they could promote autonomous 
social dialogue and collective bargaining, through the creation of an enabling legal and institutional framework, without interfering with social partner autonomy. As shown, one possibility would be to transpose in the legislation or other policy measure contents of bipartite agreements concluded by the social partners - without changing these contents. To stimulate autonomous social dialogue, governments should refrain from overregulation (which was reported as a problem in some of the countries covered in this volume) and should give the social partners space to find solutions.

Also, in complex situations, such as the current Covid-19 pandemic, the social partners, as actors in the real economy, can come together and formulate proposals to governments for measures to be taken to protect workers' jobs and income, and to promote business sustainability, as shown, for instance, in Denmark, France, Germany, Spain, and other countries (ILO 2020).

Third, digitalization is already on the policy agenda of several employers' organizations and trade unions, and several examples of social partners' initiatives - some innovative - are provided in this volume. Also, the representation of new groups of workers related to the digital revolution (freelancers, dependent self-employed and subcontracted workers) remains a topical issue. Employers' organizations and trade unions both report that small and medium-sized enterprises, which may have less capacity to adopt technological innovations and engage in social dialogue, also require special focus. Moreover, organizations in countries that have been less exposed to the technological revolution could not progress much on that front, being driven entirely by traditional concerns such as wages and working conditions. In the countries in which the social partners are involved in these issues, their activity is sometimes in the wake of, not in anticipation of, technological change.

In a number of countries the social partners reported other issues which they are trying to focus on, such as migration, as well as tackling problems associated with the 'brain drain', how migration policy can help to meet skills gaps, and how to ensure decent wages and working conditions for migrant workers. The increasing flow of European and international trade through supply chains also means that more knowledge and monitoring of working conditions of these chains is needed, from the lead firm to suppliers and subcontractors.

The survey carried out among national social partners and presented in this chapter is in line with results presented in this volume. In particular, they confirm the mixed feedback received by the social partners about their national social dialogue institutions and, more generally, about the role played by governments in encouraging autonomous social dialogue and enhancing their participation in decision-making.

On the one hand, it is encouraging to see that a majority of national trade unions and employers' organizations favour keeping those existing institutions. On the other hand, an even larger percentage indicated that they should be reformed, for example, as regards their technical capacities, mandate and scope, their method of functioning and their funding. In relation to scope, we saw that social dialogue bodies do not provide many opportunities for the social partners to influence important aspects of the future of work: digitalization and its impact on new work arrangements, productivity and growth, but also climate change and demographics. This is confirmed by a number of chapters in this volume, which also emphasize that some of those tripartite institutions were often only consultative and provide employers' and workers' organizations few opportunities 
to exercise real influence on decision-making. Our survey revealed that they rarely lead to strong outputs, such as the signature of an agreement, or to jointly defined recommendations or action plans. Even more rarely do they lead to a joint follow-up or joint implementation of work programmes or action plans. The survey also revealed that there was a need for these social dialogue institutions to be inclusive and reflect the interests and concerns of all groups of workers and employers in the labour market.

Undoubtedly, the credibility of social dialogue actors and tripartite institutions will depend on how they adjust to the new face of the world of work, and formulate adequate and innovative responses to the rapid and deep transformations currently unfolding. We hope that this research and following debates will give them ideas and inputs to address these issues and put them on their policy and operational agendas.

\section{NOTES}

1. Previous projects carried out by the ILO in cooperation with the EC led to the following publications: Europe's Disappearing Middle Class? Evidence from the World of Work (Vaughan-Whitehead 2016); Reducing Inequalities in Europe - How Industrial Relations and Labour Policies Can Close the Gap (Vaughan-Whitehead 2018); Towards Convergence in Europe - Institutions, Labour and Industrial Relations (Vaughan-Whitehead 2019).

2. Conference 'Enhancing social partners' and social dialogue's roles and capacity in the new world of work' organized by the ILO in cooperation with the EC, 5-6 March 2020, Brussels.

3. See Hayter and Visser (2018) for further details on the various types of extension mechanisms and their impact.

4. See Papadakis and Ghellab (2014) for further details.

\section{BIBLIOGRAPHY}

European Commission (EC) (2002), The European social dialogue, a force for innovation and change, Communication from the Commission, COM (2002) 341, EC: Brussels.

European Commission (EC) (2017), 'Joint Employment Report 2018: as adopted by the EPSCO Council, 15 March 2018', Directorate-General for Employment, Social Affairs and Inclusion, EC, Brussels.

Eurofound (2019), The Involvement of Social Partners in National Policymaking, Luxembourg: Publications Office of the European Union.

Hayter, S. and J. Visser (eds) (2018), Collective Agreements: Extending Labour Protection, Geneva: ILO.

International Labour Organization (ILO) (2018), 'Resolution concerning the second recurrent discussion on social dialogue and tripartism', adopted by the ILC at its one-hundred and seventh session, 25 June 2018, accessed 1 June 2021 at https://www.ilo.org/ilc/ILCSessions/previoussessions/107/reports/texts-adopted/WCMS_633143/lang--en/index.htm.

International Labour Organization (ILO) (2019), 'ILO Centenary Declaration for the Future of Work, adopted by the ILC at its one-hundred and eighth session, Geneva, 21 June 2019', accessed 15 May 2021 at https://www.ilo.org/wcmsp5/groups/public/@ed_norm/@relconf/docu ments/meetingdocument/wcms_711674.pdf.

International Labour Organization (ILO) (2020), 'The need for social dialogue in addressing the COVID-19 crisis', policy brief, May, ILO, Geneva, accessed 10 June 2021 at https://www.ilo.org/ wcmsp5/groups/public/---ed_dialogue/---dialogue/documents/briefingnote/wcms_743640.pdf.

Molina, O. (2008), 'From negotiation to imposition: social dialogue in austerity times in Spain', Transfer: European Review of Labour and Research, 14 (3), 399-418. 
Organisation for Economic Co-operation and Development (OECD) (2019), Negotiating Our Way Up: Collective Bargaining in a Changing World of Work, Paris: OECD.

Papadakis, K. and Y. Ghellab (2014), The Governance of Policy Reforms in Southern Europe and Ireland: Social Dialogue Actors and Institutions in Times of Crisis, Geneva: ILO.

Vaughan-Whitehead, D. (ed.) (2016), Europe's Disappearing Middle Class? Evidence from the World of Work, Cheltenham, UK and Northampton, MA, USA: Edward Elgar and the ILO.

Vaughan-Whitehead, D. (ed.) (2018), Reducing Inequalities in Europe - How Industrial Relations and Labour Policies Can Close the Gap, Cheltenham, UK and Northampton, MA, USA: Edward Elgar.

Vaughan-Whitehead, D. (ed.) (2019), Towards Convergence in Europe - Institutions, Labour and Industrial Relations, Cheltenham, UK and Northampton, MA, USA: Edward Elgar. 